\begin{tabular}{lccc} 
VERSITA & GOSPODARKA & SUROWCAMI & MINERALNYMI \\
\hline \multirow{2}{*}{ Tom 29} & 2013 & Zeszyt 4 \\
& & DOI 10.2478/gospo-2013-0038 &
\end{tabular}

WOJCIECH NAWORYTA*

\title{
Analysis of the sulfur content in the Gubin lignite deposit for assessing the need for sorbent and the quantity of REA gypsum produced
}

\section{Introduction}

Exploitation of the Gubin lignite deposit has been planned for the production of energy in a $2700 \mathrm{MW}$ power plant. In order to protect the atmosphere, scrubbing devices for purification of the flue gas created during the burning of lignite must be installed in the power plant. Currently, the power industry standards include dedusting installations, desulfurization plants, and installations for the reduction of nitrogen oxides.

Lignite in the Gubin deposit, as with any mineral created from plant biomass, contains sulfur which - in addition to carbon, oxygen, nitrogen, hydrogen, and phosphorous - is a basic building block of organic matter. The sulfur content in the coal seam is not constant. It varies within a certain range (Bartuś 2012). Table 1 shows the variation coefficients $v$ [\%] of sulfur compared with other parameters of selected lignite deposits. The variation coefficient $v[\%]$ is defined as the percentage ratio of standard deviation to the mean value of the parameter.

High and moderate variability in the sulfur content of the deposit makes the content of sulfur dioxide $\left(\mathrm{SO}_{2}\right)$ in the flue gas variable over the mining life of the deposit. The effect of this will be changing demand for the sorbent in flue gas desulphurisation (FGD) installations (scrubbers) and, consequently, the desulfurization product stream will be variable over time.

\footnotetext{
* Ph.D. Eng., AGH University of Science and Technology, Kraków, Poland; e-mail: naworyta@agh.edu.pl
} 
The variation coefficient $v[\%]$ of sulfur in the selected lignite deposits compared with the volatility of other structural and qualitative parameters (based on the geological documentations of the deposits)

TABELA

Współczynnik zmienności $v[\%]$ siarki w węglu wybranych złóż węgla brunatnego na tle zmienności innych parametrów strukturalnych i jakościowych (na podstawie dokumentacji geologicznej złóż)

\begin{tabular}{||l|c|c|c|c|c||}
\hline & Pątnów IV & Drzewce & Głowaczów & Jastrzębia & Gubin \\
\hline \hline Sulfur content $S[\%]$ & 23.8 & 35.0 & 25.0 & 31.2 & 40.7 \\
\hline Seam thickness $M[\mathrm{~m}]$ & 43.4 & 31.9 & 53.2 & 47.1 & 26.6 \\
\hline Calorific value Q [kJ/kg] & 16.05 & 15.0 & 15.5 & 9.4 & 8.9 \\
\hline Ash content $A[\%]$ & 44.9 & 35.47 & 29.7 & 21.0 & 36.5 \\
\hline
\end{tabular}

The purpose of this paper is to link the sulfur mass spatial variability model with the planned advances of the exploitation in order to determine the variation of the sulfur mass flow in the lignite supplied to the power plant. The problem described in the article may be classified as long-term deposit management and within the thematic area of complex management of mineral resources.

The results presented in the paper will allow for long-term planning of demand for flue gas desulfurization sorbent and the planning of the supply of raw gypsum flux as a function of time, as well as for adjusting the capacity of the future processing plant based on synthetic FGD gypsum.

\section{Flue gas desulfurization in power plants}

Just as with reclamation in surface mining, flue gas desulphurization in power plants is now a standard procedure, without which it is difficult to imagine energy production based on fossil fuels. Large-scale flue gas desulfurization in Polish power plants has been implemented since the 1990s (Uberman, Naworyta 1998). Among the many methods that are used, the most popular and most effective is the wet limestone method. Its advantages include not only high efficiency (approximately 95\%), but also a high-quality byproduct of the reaction of binding of sulfur dioxide $\left(\mathrm{SO}_{2}\right)$. After cleaning the exhaust gas stream of particulate matter (dust) in highly efficient electrostatic precipitators, the gas is passed countercurrently through a reactor in which the sulfur dioxide reacts with a sorbent. For the purposes of this article, it was assumed that in the planned power plant by the Gubin deposit just such a method will be used. The method is one which produces waste and the byproduct of desulfurization is gypsum (called REA gypsum), the properties of which do not deviate from the properties of natural gypsum. Calcium carbonate $\left(\mathrm{CaCO}_{3}\right)$ is used as the sorbent; it is a cheap and readily available raw material mined in open-pit mines. Several steps in the reaction occurring in the FGD unit can be simplified into the following equation: 


$$
\mathrm{CaCO}_{3}+2 \mathrm{H}_{2} \mathrm{O}+\mathrm{SO}_{2}+1 / 2 \mathrm{O}_{2} \rightarrow \mathrm{CaSO}_{4} \cdot 2 \mathrm{H}_{2} \mathrm{O}+\mathrm{CO}_{2}
$$

The reaction (1) produces gypsum. Its purity depends on the efficiency of the electrostatic precipitators which remove dust from the waste gases, as well as on the purity of the sorbent namely the $\mathrm{CaCO}_{3}$ content in the limestone meal. The high content of calcium carbonate is an important criterion for assessing the applicability of limestone in the FGD installation. Synthetic gypsum is now treated as an industrial raw material and is widely used in the construction industry for the manufacturing of plasterboard, adhesives and mortars, and gypsum blocks, as well as in the cement industry (Wons, Niziurska 2013).

In practice FGD gypsum is sold on the market immediately after production. In the case of lower demand for gypsum products, a storage facility should be built by the power plant a so-called anthropogenic deposit which would allow for the use of raw gypsum in the future.

For the construction of this unit, post-mining areas are preferred such as the internal dump of the mine. With currently active power plants in which flue gas desulfurization is carried out by the wet limestone method, specialized plants were established for processing synthetic gypsum into ready-to-sell products. This also created additional jobs in the mining and energy complex. Production of gypsum from the sulfur contained in the lignite using scrubbing is an example of comprehensive utilization of the deposit. Not only the lignite is burned for the purpose of energy production, but also the sulfur contained in lignite is used for production of a commercially valuable construction material.

\section{Method of analysis}

Based on data from the geological documentation for the two lignite seams planned for mining, models of the spatial variability of parameters were created thickness of the seam $M$ $[\mathrm{m}]$, and total sulfur content in the dry lignite $S_{t}{ }^{d}[\%]$. Because no correlation between the parameters $M$ and $S_{t}{ }^{d}$ was found, the models were created for each parameter separately.

Ordinary kriging and universal kriging were used as the modeling methods. Based on both variability models for $M$ and $S_{t}{ }^{d}$, for each node of the interpolation grid, the mass of the total sulfur in the raw lignite was calculated with moisture of lignite at $50 \%$. Calculations were related to the proposed five-year advances of the mining fronts. Starting with the desulfurization reaction (1), on the basis of the molecular weight of substrates and products of the reaction, the mass of limestone sorbent $\left(\mathrm{CaCO}_{3}\right)$ was calculated. This mass must be provided for the complete desulfurization of the flue gas. The mass of synthetic gypsum, which will result from the reaction $\left(\mathrm{CaSO}_{4} \cdot 2 \mathrm{H}_{2} \mathrm{O}\right)$ has also been calculated. Calculations were performed in five-year periods for part of the deposit planned for mining (Naworyta, Sypniowski 2012). To facilitate interpretation of the calculations, annual average masses of sulfur, sorbent, and gypsum are presented for the given five-year periods. Due to the limitations of advance mapping of the deposit and the imprecise nature of its long-term mining plan, a detailed analysis of the annual progress of the operational fronts was not undertaken. 


\section{The material used for analysis}

The analysis is based on data from geological boreholes listed in Appendix 1 to the geological documentation of the Gubin deposit (Bogacz et al. 2009). This document was prepared based on geological works carried out over almost half a century (in the years: 1961, 1969, 1992, 2008). As a consequence the data may differ, with the inconsistencies lying not in the variability of the deposit parameters but in the sampling methods (Mucha, Wasilewska 2013). For some parameters, such as the calorific value of lignite $Q$ or ash content $A$, differences in sampling methods may even exceed 10\% (Mazurek 2003; Naworyta, Sypniowski 2013). Given the choice of available information regarding the deposit, one should take into consideration the degree of accuracy of the analyses and incorporate this information into the conclusions of the presented forecast. Verification of the long-term forecasts will be possible after obtaining more data on the later stages of the deposit's development.

This study was based on selected, published information relating to the development of the deposit, in particular mine designs, the location of the opening cut, and the advances of the operational fronts adapted to the demands of the power plant (Naworyta, Sypniowski 2012).

\section{Results of analyses}

Figure 1 shows the experimental variograms of thickness $M[\mathrm{~m}]$ of lignite seam II and lignite seam IV in the Gubin deposit. The directional variability of the parameters was analyzed, but due to its limited influence on the modeling effect, an omnidirectional variogram model was used. The validity of such methods applied to the Gubin deposit's parameters has also been shown in the work of Kaczmarczyk et al. (Kaczmarczyk et al. 2012).

In the case of the variogram for lignite seam IV, a small number of boreholes prevented directional variability analysis. The variogram for seam IV was created after the identification of a clear trend with a second-degree polynomial adjusted to the observations. The variogram models were adjusted to the sample variograms double spherical for the thickness of seam II and single spherical for the thickness of seam IV. Model parameters are summarized in Table 2.

Figure 2 shows the variograms for the total sulfur content $S_{t}^{d}[\%]$ in lignite seam II and in lignite seam IV. Both variograms were calculated after separation of the trend with a second degree polynomial. Also in these cases the omnidirectional variogram models were used without taking the directional variability into account. The sample variogram of the total sulfur in lignite of seam II was approximated with a complex spherical model, and in the case of seam IV using a Gaussian model. The rationale for the choice of models and, above all, the procedure of separating the trend was confirmed in the cross-validation procedure. The variograms, the cross-validation, and the modeling using the kriging method were created using the program Surfer. Table 2 summarizes the variogram model parameters. 

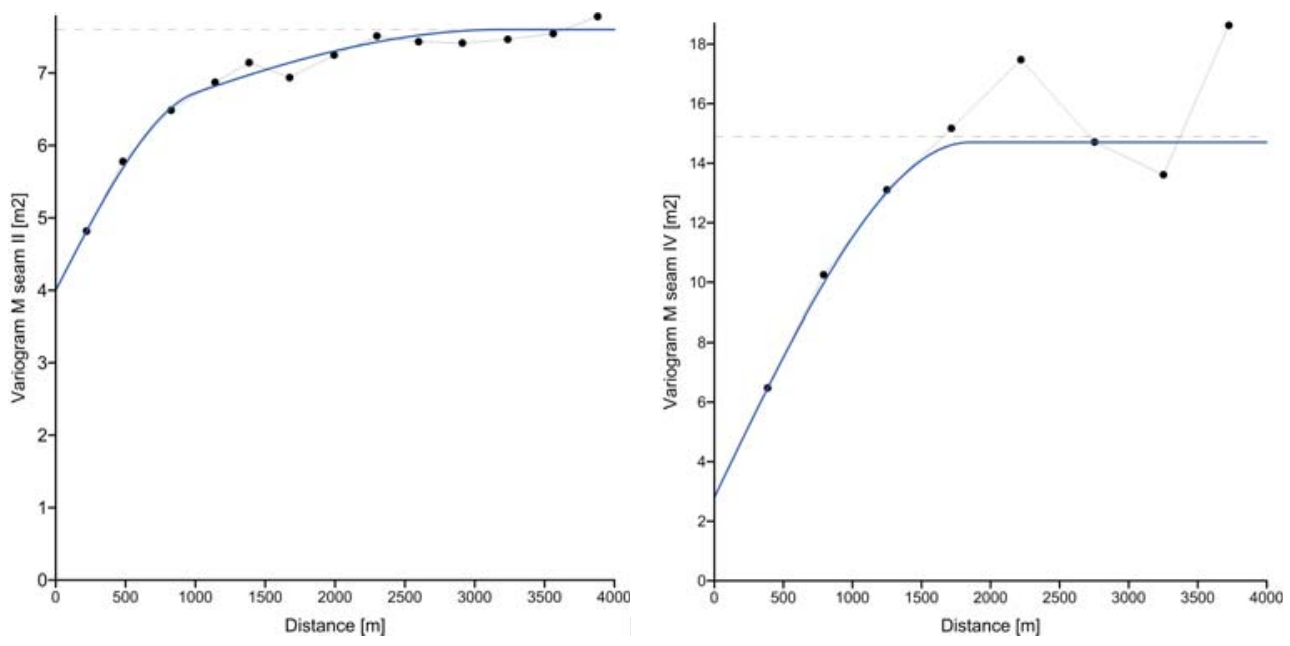

Fig. 1. The sample variograms with the models for the thickness $M[\mathrm{~m}]$ of lignite seam II (left) and in lignite seam IV (right)

Rys. 1. Wariogramy eksperymentalne wraz z modelami dla miąższości $M$ [m] pokładu II (z lewej) i pokładu IV (z prawej)
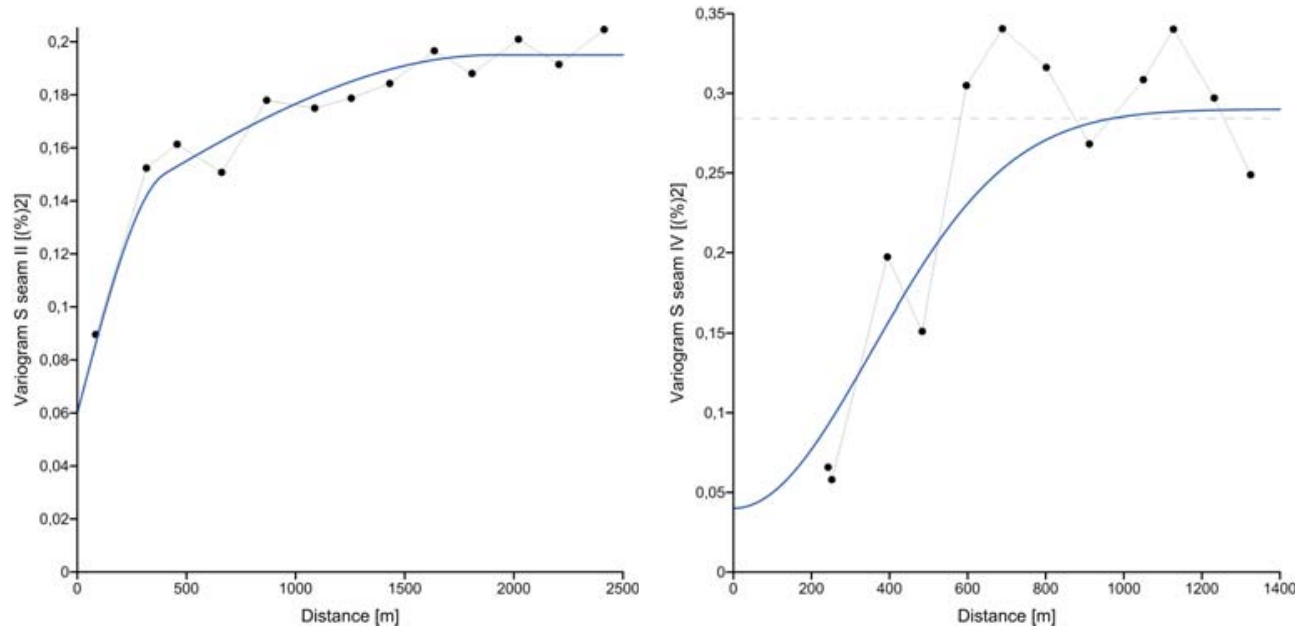

Fig. 2. The sample variograms with the models for the total sulfur content $S_{t}^{d}[\%]$ in lignite seam II (left) and lignite seam IV (right)

Rys. 2. Wariogramy eksperymentalne wraz z modelami dla zawartości siarki całkowitej $S_{t}^{d}[\%]$ w węlu pokładu II (z lewej) oraz pokładu IV (z prawej)

Due to the definition of the variogram, which has a dimension of variance, the model components' nugget effect and scale are expressed in squared units $-\mathrm{m}^{2}$ and $\%^{2}$.

Figure 3 shows the thickness distribution model $M$ of seam II (left) and seam IV (right) within the limits of the proposed operation. Figure 4 shows the sulfur distribution models 
TABLE 2

The characteristics of the variogram models for seam thickness $M$ and sulfur content in lignite seams II and IV in the Gubin deposit

TABELA 2

Charakterystyka modeli wariogramów dla miąższości i siarki pokładów II i IV złoża węgla brunatnego „Gubin”

\begin{tabular}{|c|c|c|c|c|}
\hline Model & $\begin{array}{c}\text { Thickness } \\
M[\mathrm{~m}] \\
\text { seam II } \\
\end{array}$ & $\begin{array}{c}\text { Thickness } \\
M[\mathrm{~m}] \\
\text { seam IV } \\
\end{array}$ & $\begin{array}{c}\text { Total sulfur } \\
S_{t}{ }^{d}[\%] \\
\text { seam II }\end{array}$ & $\begin{array}{c}\text { Total sulfur } \\
S_{t}{ }^{d}[\%] \\
\text { seam IV }\end{array}$ \\
\hline Nugget effect & $4 \mathrm{~m}^{2}$ & $2.8 \mathrm{~m}^{2}$ & $0.06 \% 2$ & $0.04 \% 2$ \\
\hline \multirow[b]{2}{*}{ Model 1} & Spherical & Spherical & Spherical & Gaussian \\
\hline & $\begin{array}{c}\text { Scale }-2 \mathrm{~m}^{2} \\
\text { Range }-1000 \mathrm{~m}\end{array}$ & $\begin{array}{l}\text { Scale }-11.9 \mathrm{~m}^{2} \\
\text { Range }-1850 \mathrm{~m}\end{array}$ & $\begin{array}{l}\text { Scale }-0.07 \% 2 \\
\text { Range }-400 \mathrm{~m}\end{array}$ & $\begin{array}{l}\text { Scale }-0.25 \%{ }^{2} \\
\text { Range }-500 \mathrm{~m}\end{array}$ \\
\hline \multirow[b]{2}{*}{ Model 2} & Spherical & - & Spherical & \\
\hline & $\begin{array}{c}\text { Scale }-1.6 \mathrm{~m}^{2} \\
\text { Range }-3200 \mathrm{~m}\end{array}$ & - & $\begin{array}{l}\text { Scale }-0.065 \%{ }^{2} \\
\text { Range }-1900 \mathrm{~m}\end{array}$ & \\
\hline Trend & - & $\begin{array}{c}\text { Polynomial of } 2 \mathrm{nd} \\
\text { degree }\end{array}$ & $\begin{array}{c}\text { Polynomial of } 2 \mathrm{nd} \\
\text { degree }\end{array}$ & $\begin{array}{c}\text { Polynomial of } 2 \mathrm{nd} \\
\text { degree }\end{array}$ \\
\hline
\end{tabular}
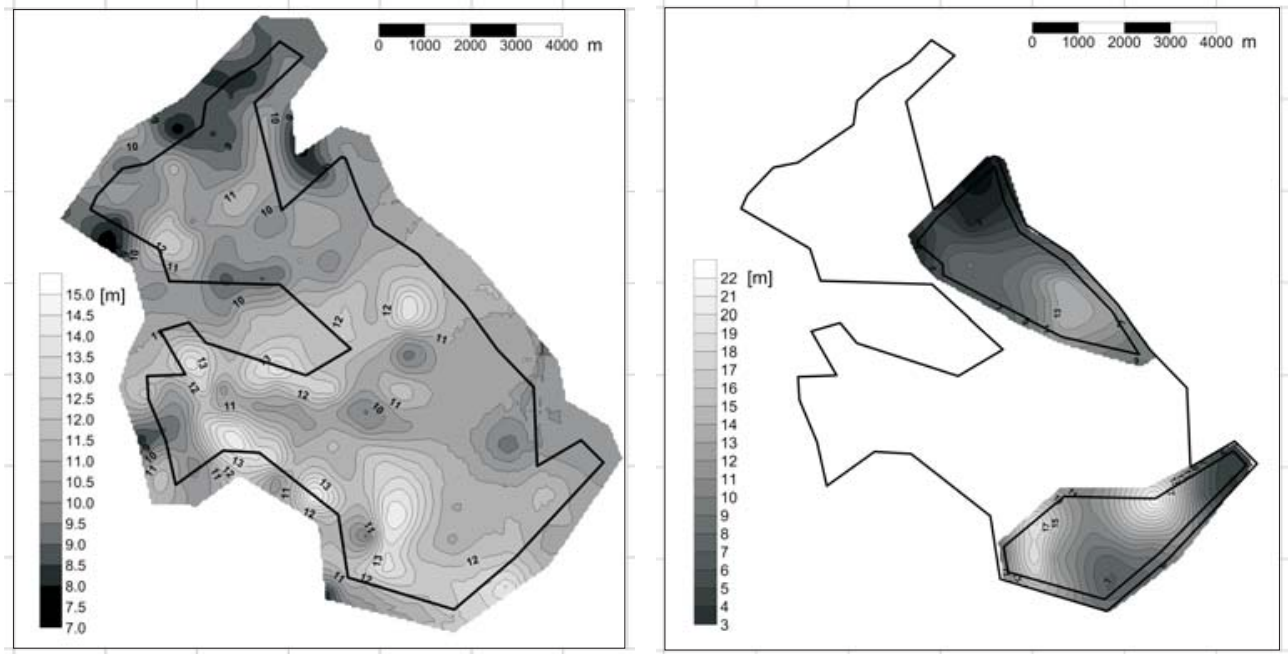

Fig. 3. Thickness distribution models $M[\mathrm{~m}]$ of lignite seam II (left) and lignite seam IV (right) within the proposed borders of mining

Rys. 3. Modele miąższości $M[\mathrm{~m}]$ pokładu węgla II (z lewej) oraz pokładu węgla IV (z prawej) w granicach projektowanej eksploatacji 

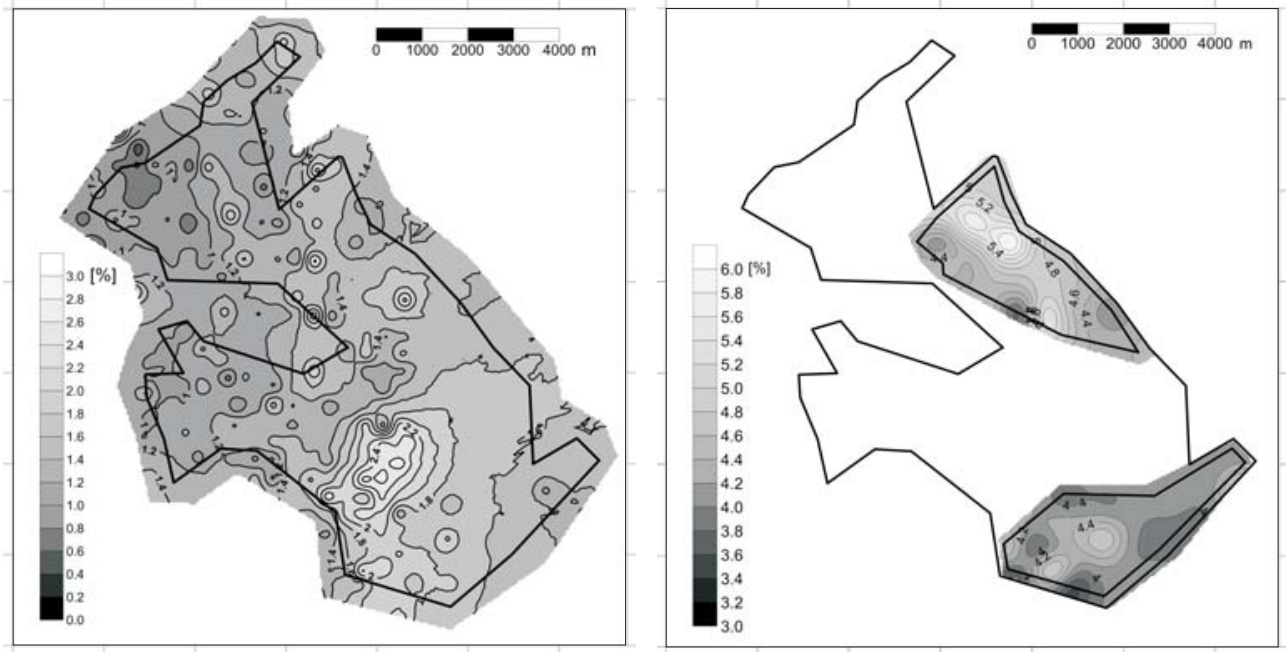

Fig. 4. The models of sulfur content distribution $S_{t}^{d}$ in the lignite of seam II (left) and lignite seam IV (right) within the limits of the proposed operation

Rys. 4. Modele zmienności zawartości siarki całkowitej $S_{t}^{d}$ w węglu w pokładzie II (z lewej) oraz w pokładzie IV (z prawej) w granicach projektowanej eksploatacji
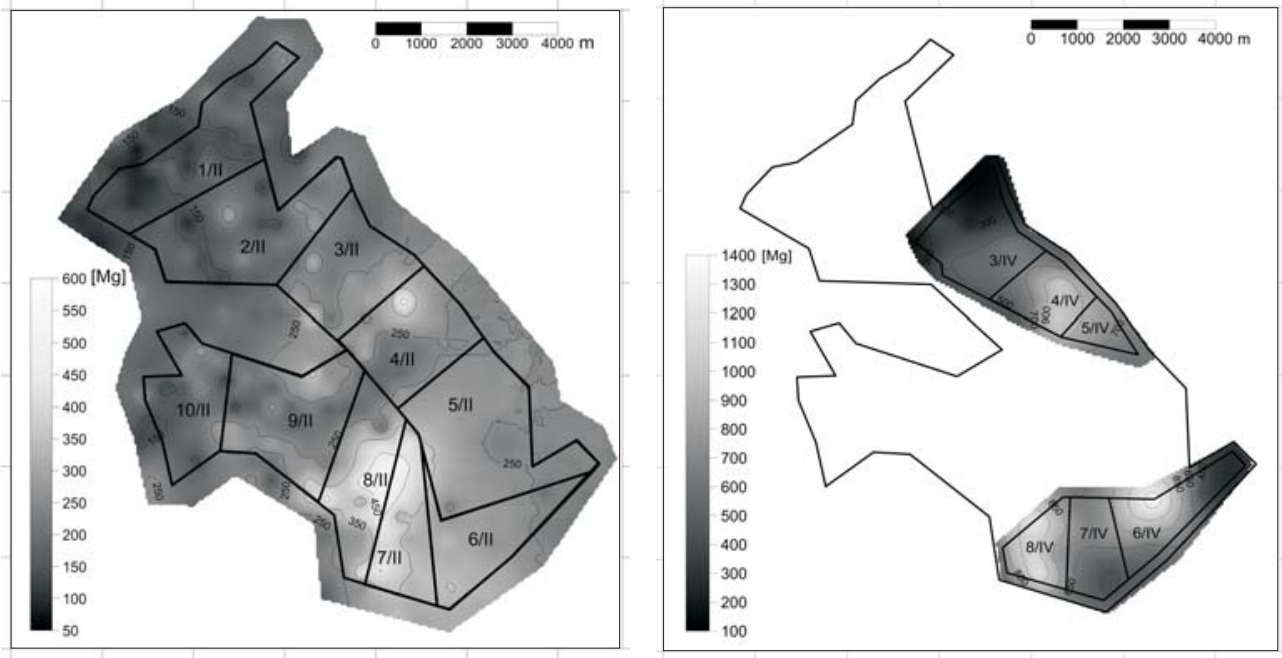

Fig. 5. Models of the sulfur mass distribution in the raw lignite in the mining blocks with dimensions of $50 \times 50$ meters in lignite seam II (left) and in lignite seam IV (right)

Rys. 5. Modele zawartości siarki w węglu w stanie surowym w blokach eksploatacyjnych o wymiarach $50 \times 50$ metrów w pokładzie II (z lewej) i w pokładzie IV (z prawej) 
$S_{t}{ }^{d}[\%]$ of lignite seam II (left) and of lignite seam IV (right). The models were created using the ordinary kriging procedure (Fig. 3 left) and universal kriging (in the remaining models) with the use of variogram models (Table 2 and Figs. 1 and 2). The basic element of the interpolation grid is $50 \times 50$ meters.

On the basis of the thickness distribution models $M$ (Fig. 3) and total sulfur content in the lignite $S_{t}^{d}$ (Fig. 4), volatility models were created of the mass of sulfur in the raw lignite in seams II and IV. For the calculation, the average moisture content of lignite was assumed at $50 \%$. Sulfur masses are referenced to the operating blocks with an area of $50 \times 50 \mathrm{~m}$ each and the thickness of lignite seam $M$ at each operating block. The spatial density of lignite was assumed at $\gamma=1,2 \mathrm{Mg} / \mathrm{m}^{2}$.

Table 3 shows the mass of sulfur in the raw lignite within the boundaries of the five-year mining advances separately for seam II, seam IV, and for both together. The graph (Fig. 6) shows the change in the amount of sulfur in the subsequent mining periods. Table 4 summarizes the average mass of sulfur, sorbent, and synthetic gypsum within the limits of the five-year mining advances. The table corresponds with the graph (Fig. 7). The boundaries of the five-year mining advances are described in the drawings.

TABLE 3

Mass of sulfur in lignite in seam II, seam IV, and both together within the limits of the five-year mining advances $[000 \mathrm{~s} \mathrm{Mg}]$

TABELA 3

Masy siarki w węglu w pokładach węgla II i IV oraz łącznie w granicach pięcioletnich postępów eksploatacji [tys. Mg]

\begin{tabular}{||c|c|c|c|c|c|c|c|c|c|c||}
\hline \multicolumn{1}{|c|}{ Periods } & 1 & 2 & 3 & 4 & 5 & 6 & 7 & 8 & 9 & 10 \\
\hline \hline$S_{50 \%}$ II & 387.7 & 574.5 & 490.0 & 524.9 & 910.2 & 504.3 & 549.5 & 633.9 & 606.2 & 320.0 \\
\hline$S_{50 \%}$ IV & 0 & 0 & 654.3 & 705.5 & 289.8 & 848.9 & 582.9 & 710.0 & 0 & 0 \\
\hline$S_{50 \%}$ II + IV & 387.8 & 574.5 & 1144.3 & 1230.4 & 1200.0 & 1353.2 & 1132.4 & 1343.9 & 606.2 & 320.1 \\
\hline
\end{tabular}

Annual average mass of sulfur, sorbent, and synthetic gypsum during the five-year advances of mining $[000 \mathrm{~s} \mathrm{Mg}]$

TABELA 4

Średnioroczne masy siarki, sorbentu i gipsu syntetycznego w granicach pięcioletnich postępów eksploatacji złoża [tys. Mg]

\begin{tabular}{||l|c|c|c|c|c|c|c|c|c|c||}
\hline \multicolumn{1}{|c|}{ Periods } & 1 & 2 & 3 & 4 & 5 & 6 & 7 & 8 & 9 & 10 \\
\hline \hline$S_{50 \%}$ & 77.6 & 114.9 & 228.9 & 246.1 & 240.0 & 270.6 & 226.5 & 268.8 & 121.2 & 64.0 \\
\hline $\mathrm{CaCO}_{3}$ & 242.3 & 359.0 & 715.2 & 769.0 & 750.0 & 845.8 & 707.7 & 839.9 & 378.9 & 200.0 \\
\hline Gypsum & 416.8 & 617.5 & 1230.1 & 1322.7 & 1290.0 & 1454.7 & 1217.3 & 1444.7 & 651.7 & 344.1 \\
\hline
\end{tabular}




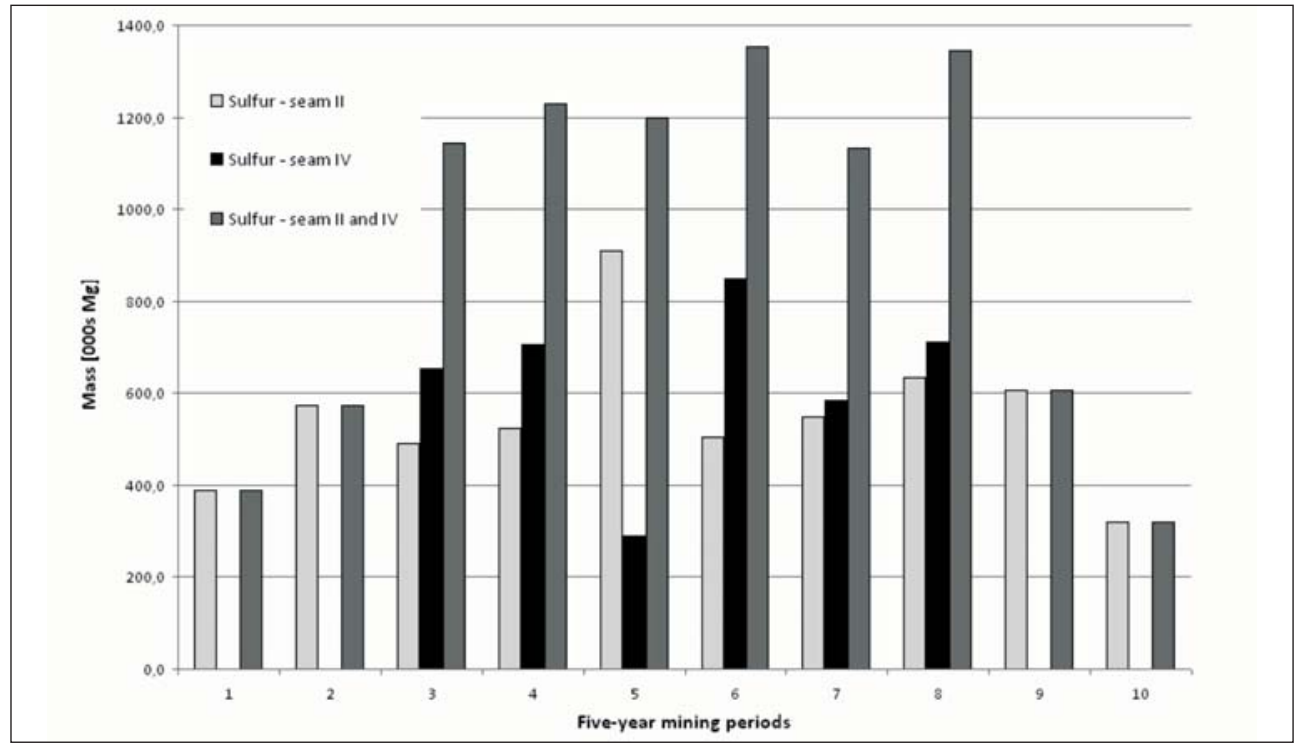

Fig. 6. Sulfur mass in the lignite in seam II, seam IV, and in both together during five years of operation $[000 \mathrm{~s} \mathrm{Mg}]$

Rys. 6. Masa siarki w węglu w stanie surowym w pokładach II, IV oraz łącznie w granicach pięcioletnich postępów eksploatacji [tys. Mg]

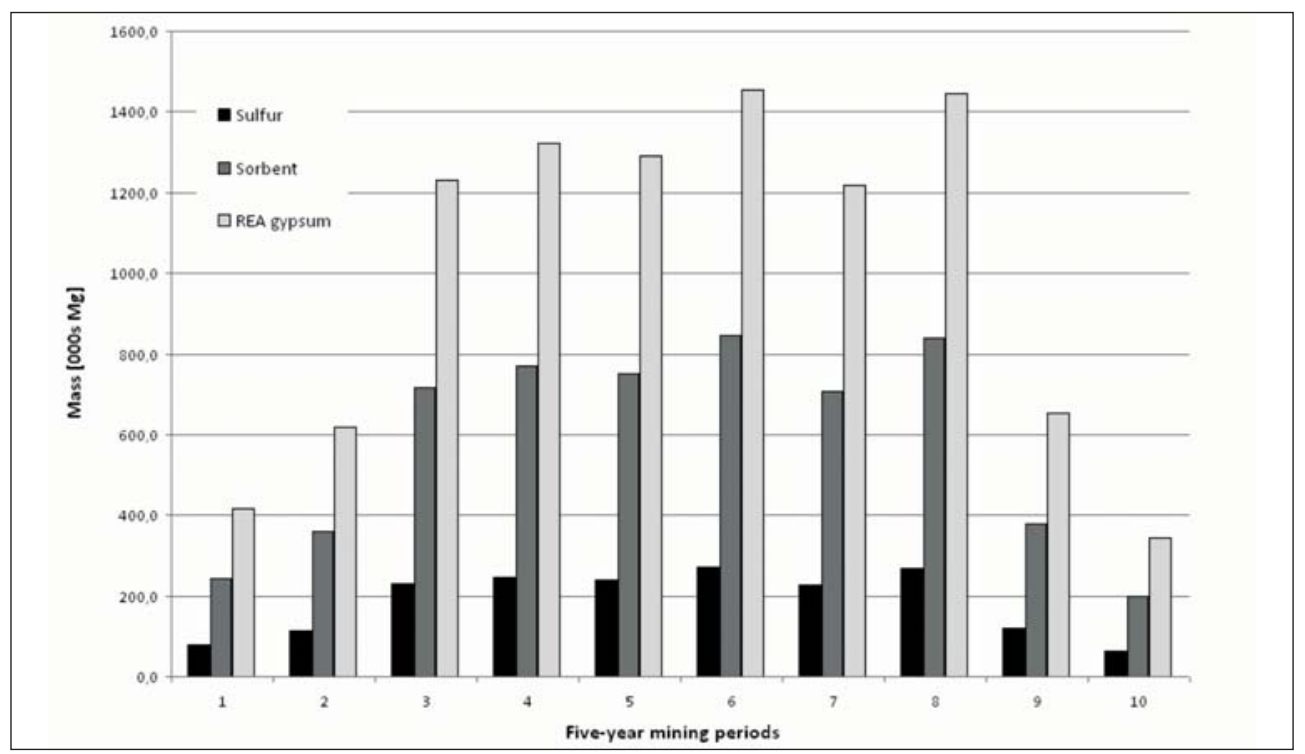

Fig. 7. Annual average mass of sulfur, sorbent, and synthetic gypsum during the five-year advances of mining $[000 \mathrm{~s} \mathrm{Mg}]$

Rys. 7. Średnioroczne masy siarki, sorbentu i gipsu syntetycznego w granicach pięcioletnich postępów eksploatacji złoża [tys. Mg] 


\section{Summary and conclusions}

The quantities of sulfur, sorbent, and gypsum presented in Tables 3 and 4 should be interpreted taking into account the accuracy of geological information, based on which the computations were performed. Within the limits of the proposed operation, the exploration is irregular in the eastern part within the limits of the five-year periods numbered 4-7 the bed is only recognized in the $\mathrm{C}_{2}$ category. For this reason, during the actual exploitation phase differences may occur in relation to the estimates presented in the paper. Forecasts of demand for sorbent should be reviewed in the next stages associated with the development of the deposit as additional information on the quality of coal in the deposit becomes available.

Based on the results, the following statements can be made:

- Models of sulfur content distribution $S_{t}^{d}$ [\%] (Fig. 4) only partially inform about the future needs related to scrubbing. For this kind of interpretation of the deposit, the spatial distribution of the mass of sulfur $S[\mathrm{Mg}]$ in the operational blocks in the raw lignite, created taking into account the thickness of the each seam $M[\mathrm{~m}]$ (Fig. 5), are much more useful.

- The sulfur content in the lignite has a high spatial variability - both in seam II and in seam IV (Figs. 4 and 5). The lignite in seam II has an average sulfur content. Increased amounts of sulfur are present in the eastern part of the seam in the area between the borders of the five-year mining periods no. 7 and 8 .

- Lignite in seam IV contains more sulfur. Mining of this seam will result in an increase in the total amount of sulfur in the lignite stream.

- As of the third, five-year period to the end of the eighth period it will be necessary to provide more of the desulfurization sorbent, which will also cause a higher supply of REA gypsum than in the initial and final periods of exploitation.

The results presented in the paper may be useful for evaluating the impact of synthetic gypsum supply on the market for this commodity in the country. This assessment, due to the multiplicity of factors that need to be taken into account, will be the subject of a separate report which will be incorporated into strategies for energy development based on lignite and hard coal. A similar forecast was already done in the 1990s during a period of intense modernization of power plants for flue gas desulfurization (Uberman, Naworyta 1998). Due to the passage of time and the changes that have taken place in the energy production market, it is necessary to revise the forecast.

\section{REFERENCES}

Bartuś T., 2012 - Anizotropia zmienności głównych parametrów jakości węgla brunatnego w polu Bełchatów, Mineral Resources Management (Gospodarka Surowcami Mineralnymi) t. 28, z. 2, s. 5-29, Wyd. IGSMiE PAN, Kraków.

Bogacz et al. 2009 - B o ga z A A., S aw icka K., S ok ołowski M., K waśniewska S., 2009 - Dodatek nr 1 do dokumentacji geologicznej złoża węgla brunatnego Gubin w kategorii $\mathrm{B}+\mathrm{C}_{1}+\mathrm{C}_{2}$, Appendix 1 to the 
geological documentation of the Gubin lignite deposit in the category $\mathrm{B}+\mathrm{C}_{1}+\mathrm{C}_{2}$. Przedsiębiorstwo Geologiczne w Krakowie, CAG PIG nr 3090/2009, Warszawa.

Kaczmarczyk et al. 2012 - Kaczmarczyk M., Nieckula M., Mucha J., Wasilewska-Błaszczyk M., 2012 - Praktyczne konsekwencje geostatystycznego badania struktury zmienności parametrów złoża węgla brunatnego Gubin i siarki Osiek. Practical consequences of a geostatistical study of the varying parameters of the Gubin lignite and Osiek sulphur deposits. Zeszyty Naukowe IGSMiE PAN, z. 83, pp. 51-68.

Ma zu rek S., 2003 - Zależność wyników analiz zapopielenia węgla brunatnego od systemu wiercenia i opróbowania, a możliwości prognozowania parametrów dostaw - na przykładzie złóż konińskich. Węgiel Brunatny nr 2 (43).

Mucha J., Wasilewska-Błaszczyk M., 2013 - Opróbowanie złóż do badań chemicznych i jego dokumentowanie - oczekiwania i rzeczywistość. Sampling of deposits for chemical analyses and its reporting expectations and reality. Surface Mining (Górnictwo Odkrywkowe) No 2/2013, pp. 52-57.

Naworyta W., Sypniowski S., 2012 - Zagospodarowanie złoża węgla brunatnego Gubin - wybrane problemy projektowania kopalni. Development of the Gubin lignite deposit - selected aspects of mine desing, Energy Policy Journal (Polityka Energetyczna) Vol. 15, issue 3, pp. 108-134.

Naw oryta W., Sypniowski S., 2013 - O problemie sterowania jakością strugi urobku w kopalniach węgla brunatnego w kontekście właściwego rozpoznania parametrów jakościowych złoża. About the problem of lignite stream quality control in the context of proper identification of deposit's quality parameters. Surface Mining (Górnictwo Odkrywkowe) No 2/2013, pp. 58-65.

Uberman R., Naw oryta W., 1998 - Odpadowe surowce mineralne z instalacji odsiarczania spalin w elektrowniach opalanych węglem brunatnym jako baza surowcowa dla produkcji wyrobów gipsowych. Sympozja i Konferencje nr 33, Wyd. IGSMiE PAN Kraków.

Wons T., Niziurska M., 2013 - Analiza jakości gipsów syntetycznych z krajowych instalacji odsiarczania spalin metodą mokrą wapienną stosowanych jako substytut gipsu naturalnego do produkcji wyrobów budowlanych. Instytut Ceramiki i Materiałów Budowlanych w Krakowie.

ANALIZA ZMIENNOŚCI ZAWARTOŚCI SIARKI W WĘGLU ZLOŻA GUBIN POD KĄTEM

OCENY ZAPOTRZEBOWANIA NA SORBENT ORAZ PRODUKCJI REA-GIPSU W PLANOWANEJ ELEKTROWNI

\section{Słowa kluczowe}

Odsiarczanie spalin, węgiel brunatny, planowanie długoterminowe, złoże Gubin, gips syntetyczny

\section{Streszczenie}

Artykuł dotyczy kompleksowej gospodarki zasobami złoża, w szczególności długoterminowego planowania zagospodarowania złoża węgla brunatnego. Na podstawie danych z dokumentacji geologicznej złoża Gubin przeanalizowano zmienność zawartości siarki całkowitej w przeznaczonych do eksploatacji pokładach węgla pod kątem ilości sorbentu potrzebnego do odsiarczania spalin oraz ilości produktów ubocznych tego procesu.

Do modelowania parametrów złoża wykorzystano metody geostatystyczne, kriging zwyczajny i uniwersalny. Na podstawie projektu eksploatacji złoża określono ilość siarki całkowitej w węglu w granicach projektowanych pięcioletnich postępów frontów eksploatacyjnych. W analizie uwzględniono planowaną równoległą eksploatację dwóch pokładów węgla.

Założono, że do odsiarczania spalin w elektrowni zastosowana będzie metoda mokra wapienna.

Na podstawie równania reakcji jaka zachodzi w procesie odsiarczania spalin w metodzie mokrej wapiennej obliczono masę sorbentu $\left(\mathrm{CaCO}_{3}\right)$ jaką trzeba będzie zapewnić dla całkowitego odsiarczenia spalin oraz masę gipsu, który będzie produktem odsiarczania.

Analizy wykazały, że ze względu na podwyższoną zawartość siarki w głębszym pokładzie węgla w okresie jego eksploatacji wystąpi zwiększone zapotrzebowanie na sorbent i w konsekwencji wystąpi zwiększona podaż gipsu odpadowego. 
Wyniki długookresowej analizy mogą być przydatne do określenia ilości sorbentu w długim okresie czasu oraz dla projektowania zagospodarowania produktów ubocznych odsiarczania spalin przy elektrowni na złożu Gubin. Wyniki mogą być również przydatne do długookresowej oceny wpływu podaży gipsu syntetycznego na rynek tego surowca w kraju.

\section{ANALYSIS OF THE SULFUR CONTENT IN THE GUBIN LIGNITE DEPOSIT FOR ASSESSING THE NEED FOR SORBENT} AND THE QUANTITY OF REA GYPSUM PRODUCED

\section{Key words}

Desulfurization, lignite, long-term planning, the Gubin deposit, synthetic gypsum

\section{Abstract}

The paper refers to the problem of complex management of mineral resources, especially to the long-term lignite deposit management. Based on data from the geological documentation of the Gubin deposit, this article analyzes the variability of total sulfur content in lignite seams planned for exploitation. The purpose of this analyzes is the assessment of the amount of sorbent required for desulfurization process and the quantity of byproduct of this process. For modeling of the deposit's parameters, geostatistical methods were used including ordinary and universal kriging. Given the mining design, the total amount of sulfur in the lignite was determined within the proposed five-year advances of the exploitation fronts. The analysis took into account the planned, simultaneous mining of two lignite seams. For the purposes of this article, it was assumed that in the planned power plant by the Gubin deposit wet limestone scrubbing method will be used. Using the equation for the reaction that takes place in the flue gas desulfurization process, the mass of sorbent $\left(\mathrm{CaCO}_{3}\right)$ was calculated which will be needed for total gas desulfurization, as well as the mass of the gypsum which will be the product of this process.

The lower lignite seam contains increased amount of the sulfur. Mining of this seam will cause significant increase of the demand on the desulfurization sorbent and, consequently, the higher supply of REA gypsum.

The results of the analysis may be useful to determine the amount of sorbent required in the long term and for the development of a desulphurization byproducts management plan at the power plant located by the Gubin deposit. They can also be used for evaluating the impact of synthetic gypsum supply on the market for this commodity in the country. 